\title{
Strength of the Partial Replacement of Cement by using Rice Husk Ash
}

\author{
Thendral Sundararasan.S, Arunya. A, Chitra.R
}

\begin{abstract}
In these papers present we have replaced with cement by rice husk ash concrete which contains silica. Rice being the staple food of the Indian Subcontinent, huge quantities of paddy is grown, milled to yield rice and byproduct, rice husk, is going as waste material in the absence suitable recycling technology till recently. Rice husk when burnt yields ash with 80 to 90 percent of silica depending upon the temperature of burning. Extensive studies conducted have revealed that the concrete made of cements partially replaced by rice husk ash yielded good concrete with high early strengths. The replacement is 30 percent in 1:1.6:2.8 mix ratio with water cement Ratio 0.5. The study present with the strength properties of compressive strength for cube and cylinder split tensile strength, modulus of rupture. Rice husk ash considerable increased strength for partial replacement and disposal of Partial replacement of cement by rice husk ash considerable increase strength and disposal of rice husk is also considerably reduced.
\end{abstract}

\section{Keywords: - Mechanical properties, Rice husk}

\section{INTRODUCTION}

\section{A. GENERAL}

Concrete is basically a mixture of three components as well as cement with water, coarse aggregates and fine aggregate. The cement is the binding materials and coarse aggregates contribute of strength and fine aggregates are filler materials. The materials composed of cement and water, and it binds together the fine aggregates and coarse aggregates. Some of the reports have been presented in these papers $\mathrm{Mr}$. V. Seshagiri Rao and Mr. A. Prasada Rao have carried out research on "Durability of rice husk cement concrete". The different grades of concretes made with replacement of cement by rice husk ash are comparable in strength with no ash concrete even at $30-40 \%$ of replacement of cement by ash. The rice husk ash concretes are less permeable than concretes with no ash for different grades. The rice husk ash concretes are more resistant to abrasion and it is found to be about twenty percent. The rice husk ash concrete offer more resistance to dilute acids, the resistance being very high for

Revised Manuscript Received on October 22, 2019.

S. Thendral, Assistant Professor,,Department Of Civil Engineering,,Bharath Institution Of Higher Education And Research,TamilNadu, India .Email: thendral.cs@gmail.com

A.Arunya, Asistant Professor, Department Of Civil Engineering,.Bharath Institution of Higher Education And Research,TamilNadu, India Email: arunyaaaa@gmail.com

R. Chitra, Asistant Professor, Department Of Civil Engineering,,Bharath Institution of Higher Education And Research,TamilNadu, India Email: chitraroopauma@gmail.com sulphuric acid, followed by acetic acid and hydrochloric acid. G. V. Rama Rao and M. V. Seshagiri Rao have carried out research on "Improvement in Durability Characteristics of Concrete Using Pozzolanic Material as Admixture". There is an improvement for abrasion in RHA concretes upto $40 \%$ replacement. The resistance of RHA concretes is improved sufficiently more so in the case of $\mathrm{H} 2 \mathrm{SO} 4$. According to Rice husk ash is to contribute to the concrete strength. The rice husk ash is lead to increase shrinkage problem but this has not been confirmed. To achieve adequate workability the use of super plasticizers may be necessary.[2]-[8]

\section{MATERIALS AND MIX PROPORTIONS}

\section{A. Materials}

The grade of concrete M20 mix is used as per IS 10262-2009. The mix ratio found to be 1:1.6:2.8:0.5 respectively. Plain cement concrete without Rice husk ash for the above proportion is prepared.

\section{B. Mix Proportions}

In the mix proportion Rice Husk Ash concrete six different mixes were prepared. In each stage the cement was replaced by RHA in proportion of 5\%, 10\%, 15\%, 20\%, 25\%, and 30\% by weight. All the mix was prepared and tested in the laboratory.

\section{Scope and Objectives}

\section{i. Objectives}

To study about mechanical properties of Rice Husk Ash concrete in compressive strength for cube and cylinder, modulus of rupture, split tensile strength compare the same with plain cement concrete for water cement ratio 0.5 . The rice husk ask 5-10 percentages with replacement of cement and their properties are to be investigated and compared to the plain cement concrete.

\section{METHODOLOGY}

\section{A. Test Methods and Preparation of Specimen}

\section{Workability of Concrete}

Workability test were tested on fresh concrete during casting of specimens.

Slump cone Test and Factor of Compaction test were \\ Blue Eyes Intelligence Engineering}


conducted for all proportions of concrete mix to analysis the workability of concrete. Table1 Show slump values and compaction factor of fresh concrete. [10]-[15]

\section{B. Compressive Strength Test}

The Compression tests were carried out 3rd day, 7th day and 28th day strength of cubes for all mix proportion of concrete was found out, 3 nos of specimen each. Similarly 28th day compressive strength of cylinders for all the mix proportion of concrete, 3 nos of specimen each were found out.

\section{Split tensile strength test}

Split tensile strength tested for all the mix proportion of concrete at 28 days.

\section{Test for modulus of rupture}

Three numbers of beams of size $100 \mathrm{~mm} 100 \mathrm{~mm} 500 \mathrm{~mm}$ were tested for modulus of rupture for all the mix proportion of concrete conducted on 28th day.[16]-[21]

D. Preparation of Test Specimen

\begin{tabular}{|c|c|c|c|}
\hline Identification & $\begin{array}{l}\text { Cement + } \\
\text { RHA }\end{array}$ & $\begin{array}{l}\text { Slump } \\
\text { value in } \\
\text { cm }\end{array}$ & $\begin{array}{l}\text { Compaction } \\
\text { Factor }\end{array}$ \\
\hline RHA 00 & $\begin{array}{l}100 \%+ \\
00 \%\end{array}$ & 5 & 0.97 \\
\hline RHA 05 & $\begin{array}{l}95 \% \\
05 \%\end{array}$ & 4 & 0.95 \\
\hline RHA 10 & $\begin{array}{l}90 \% \\
10 \% \\
\end{array}$ & 3 & 0.93 \\
\hline RHA 15 & $\begin{array}{l}85 \% \\
15 \% \\
\end{array}$ & 2 & 0.90 \\
\hline RHA 20 & $\begin{array}{l}80 \% \\
20 \% \\
\end{array}$ & 1 & 0.85 \\
\hline RHA 25 & $\begin{array}{l}75 \% \\
25 \% \\
\end{array}$ & 0.5 & 0.82 \\
\hline RHA 30 & $\begin{array}{l}70 \% \\
30 \% \\
\end{array}$ & 0.5 & 0.79 \\
\hline
\end{tabular}

Casting of Cubes Nine concrete cubes of size $150 \mathrm{mmx} 150 \mathrm{mmx} 150 \mathrm{~mm}$ of the above mix in each mix proportion were prepared. Casting of Cylinders Six concrete cylinders of size $(150 \mathrm{mmx} 300 \mathrm{~mm})$ using the above mix in each mix proportion were prepared Casting of Flexure Beams Three concrete beams of size $100 \mathrm{~mm} \times 100 \mathrm{~mm} \times 500 \mathrm{~mm}$ of the above mix in each mix proportion were prepared.[22]-[25]

\section{RESULTS \& DISCUSSION}

\section{A. Workability test}

The workability of fresh concrete reduced gradually increased Rice Husk Ash in the percentage. The Slump cone value is reduced up to $5 \mathrm{~cm}$ to $0.5 \mathrm{~cm}$ compare with the plain cement concrete to $30 \%$ replacement of cement by Rice Husk Ash. The factor Compaction is reduced up to 0.98 to 0.79 compared to the plain cement concrete. Fig 8.1 and 8.2 shows the reduction in value of the slump and compaction factor.[26]-[30]

\section{B. Compressive Strength concrete}

The $3^{\text {th }}$ and $7^{\text {th }}$ day strength of Rice Husk Ash cement concretes is reduced compared to conventional cement concrete. The 28th day strength of concrete is increased $20 \%$ replacement of cement by Rice Husk Ash. For concrete with
$5 \%$ replacement of cement by Rice Husk Ash increase strength of cube is $2.3 \%$, increase in strength of cylinder is $23.4 \%$. For concrete with $10 \%$ replacement of cement by Rice Husk Ash increase in strength of cube is $2.3 \%$, increase strength of cylinder is $19.0 \%$. For concrete with replacement $15 \%$ of cement by Rice Husk Ash increase in strength of cube is $1.7 \%$, increase in strength of cylinder is $16.9 \%$. For concrete with replacement $20 \%$ of cement by Rice Husk Ash strength of cube is equal and increase in strength of cylinder is $7.4 \%$. For concrete with more than $20 \%$ replacement of cement by there is reduction in strength of cube and in strength of cylinder. The ratios strength of Rice Husk Ash cement concrete of all mixes is more than those of plain cement concrete.[22]-

\section{Split Tensile Strength of concrete}

The strength of the cubes and cylinder 5\% replacement of cement by Rice Husk Ash to increased strength $10 \%$ and $6.5 \%$.

\section{Modulus of Rupture}

The beam strength is increased for mixes with replacement $15 \%$ cement by Rice Husk Ash. For concrete with replacement $5 \%$ of cement by Rice Husk Ash increase in modulus of rupture of beam is $8.6 \%$. For concrete with replacement $15 \%$ of cement by RHA increase in modulus of rupture of beam is $8.6 \%$. For concrete with replacement $20 \%$ of cement by RHA increase in modulus of rupture of beam is $1.7 \%$. For concrete with more than replacement $15 \%$ of cement by Rice Husk Ash these is reduction in modulus of rupture of beam.

\begin{tabular}{|c|c|l|l|l|}
\hline \multicolumn{5}{|c|}{ Compressive Strength of Cubes } \\
\hline Identification & $\begin{array}{c}\text { Cement + } \\
\text { RHA }\end{array}$ & 3 days & 7 days & 28 days \\
\hline RHA 00 & $100 \%+00 \%$ & 22.8 & 28.7 & 34.8 \\
\hline RHA 05 & $95 \%+05 \%$ & 20 & 26.8 & 35.6 \\
\hline RHA 10 & $90 \%+10 \%$ & 17.2 & 24.3 & 35.6 \\
\hline RHA 15 & $85 \%+15 \%$ & 15.4 & 23.8 & 35.4 \\
\hline RHA 20 & $80 \%+20 \%$ & 13 & 21.5 & 34.4 \\
\hline RHA 25 & $75 \%+25 \%$ & 11.7 & 17.0 & 26 \\
\hline RHA 30 & $70 \%+30 \%$ & 10.5 & 16.2 & 23.6 \\
\hline
\end{tabular}

Table 3: The split Tensile Strength of Cylinders and modulus of rupture of beam

Published By:

Blue Eyes Intelligence Engineering 


\begin{tabular}{|c|c|c|c|c|}
\hline \multicolumn{5}{|c|}{ Split Tensile Strength of Cylinders and modulus of rupture of } \\
Identification & $\begin{array}{c}\text { Bement }+ \\
\text { RHA }\end{array}$ & $\begin{array}{c}\text { Split Tensile } \\
\text { Strength of } \\
\text { Cylinders in } \\
\text { N/mm2 }\end{array}$ & $\begin{array}{c}\text { Modulus of } \\
\text { Rupture of } \\
\text { Beams in } \\
\text { N/mm2 }\end{array}$ & $\begin{array}{c}\text { Ratio of } \\
(\mathbf{1}) /(2)\end{array}$ \\
\hline RHA 00 & $\begin{array}{c}100 \%+ \\
00 \%\end{array}$ & 3.1 & 5.8 & 0.53 \\
\hline RHA 05 & $\begin{array}{c}95 \%+ \\
05 \%\end{array}$ & 3.3 & 6.3 & 0.52 \\
\hline RHA 10 & $\begin{array}{c}90 \%+ \\
10 \%\end{array}$ & 3.3 & 6.3 & 0.52 \\
\hline RHA 15 & $\begin{array}{c}85 \%+ \\
15 \%\end{array}$ & 2.8 & 5.9 & 0.47 \\
\hline RHA 20 & $\begin{array}{c}80 \%+ \\
20 \%\end{array}$ & 2.6 & 5.8 & 0.45 \\
\hline RHA 25 & $\begin{array}{c}75 \%+ \\
25 \%\end{array}$ & 2.3 & 5.1 & 0.45 \\
\hline RHA 30 & $\begin{array}{c}70 \%+ \\
30 \%\end{array}$ & 1.9 & 5.0 & 0.38 \\
\hline
\end{tabular}

\section{CONCLUSIONS}

Based on the experimental investigation on cement concrete and cement concrete with Rice Husk Ash, the following conclusions have been made.[31]-[34]

- The Rice Husk Ash replacement of cement is counteracting the initial strength of concrete that is 3rd day and 7 th day. But the 28th day concrete strength is increasing as compared to the plain cement concrete.

- The Rice husk ash $10 \%$ replacement of cement by the characteristic strength of concrete increases, further increasing Rice Husk Ash content results in reducing strength. - The Rice husk ash $20 \%$ replacement of cement, the characteristic strength of concrete almost equal compared to the plain cement concrete.

- The Rice husk ash $10 \%$ replacement of cement in concrete is selected as optimum mix proportion.

- The Rice husk ash $20 \%$ replacement of cement in concrete is selected as maximum mix proportion.

- The addition of Rice husk ash reduces the concrete workability and it requires more compaction, super plasticizers may be added to increase the concrete workability.

- Rice Husk Ash disposal is a serious problem; this may be rectified by using this as ingredient for concrete.

\section{REFERENCES}

1. Iyappan L., Dayakar P., Identification of landslide prone zone for coonoortalukusing spatial technology, International Journal of Applied Engineering Research,V-9,I-22,PP-5724-5732,Y-2014.

2. Kumar J., Sathish Kumar K., Dayakar P.,Effect of microsilica on high strength concrete, International Journal of Applied Engineering Research,V-9,I-22,PP-5427-5432,Y-2014

3. Dayakar P., Vijay Ruthrapathi G., Prakesh J., Management of bio-medical waste, International Journal of Applied Engineering Research,V-9,I-22,PP-5518-5526,Y-2014.

4. Swaminathan N., Dayakar P., Resource optimization in construction project, International Journal of Applied Engineering Research,V-9,I-22,PP-5546-5551,Y-2014.

5. Venkat Raman K., Dayakar P., Raju K.V.B.,An experimental study on effect of cone diameters in penetration test on sandy soil,
International Journal of Civil Engineering and Technology,V-8,I-8,PP-1581-1588,Y-2017.

6. Saritha B., Chockalingam M.P.,Photodradation of malachite green DYE using TIO2/activated carbon composite,International Journal of Civil Engineering and Technology,V-8,I-8,PP-156-163,Y-2017

7. Shendge R.B., Chockalingam M.P., Saritha B., Ambica A.,Swat modelling for sediment yield: A case study of Ujjani reservoir in Maharashtra, India,International Journal of Civil Engineering and Technology,V-9,I-1,PP-245-252,Y-2018

8. Chockalingam M.P., Balamurgan V.,Modernisation of an existing urban road-sector in Chennai, a case study report,International Journal of Civil Engineering and Technology,V-8,I-8,PP-1457-1467,Y-2017

9. Saritha B., Chockalingam M.P.,Adsorption study on removal of basic dye by modified coconut shell adsorbent, International Journal of Civil Engineering and Technology,V-8,I-8,PP-1370-1374,Y-2017

10. Saritha B., Chockalingam M.P.,Adsorptive removal of heavy metal chromium from aqueous medium using modified natural adsorbent,International Journal of Civil Engineering and Technology,V-8,I-8,PP-1382-1387,Y-2017

11. Chockalingam M.P., Palanivelraja S.,Retrospective analysis of a theoretical model used for forecasting future air quality near the north Chennai thermal power plant,International Journal of Civil Engineering and Technology,V-8,I-8,PP-1457-1467,Y-2017

12. Saritha B., Chockalingam M.P.,Photodegradation of methylene blue dye in aqueous medium by $\mathrm{Fe}-\mathrm{AC} / \mathrm{TiO} 2$ Composite,Nature Environment and Pollution Technology,V-17,I-4,PP-1259-1265,Y-2018

13. Shendge R.B., Chockalingam M.P., Kaviya B., Ambica A.,Estimates of potential evapotranspiration rates by three methods in upper Bhima Basin, In Maharashtra, India,International Journal of Civil Engineering and Technology,V-9,I-2,PP-475-480,Y-2018

14. Shendge R.B., Chockalingam M.P.,The soil and water assessment tool for Ujjani Reservoir,International Journal of Mechanical Engineering and Technology,V-9,I-2,PP-354-359,Y-2018

15. Shendge R.B., Chockalingam M.P.,A review on soil and water assessment tool,International Journal of Mechanical Engineering and Technology,V-9,I-2,PP-347-353,Y-2018

16. Sachithanandam P., Meikandaan T.P., Srividya T.,Steel framed multi storey residential building analysis and design,International Journal of Applied Engineering Research,V-9,I-22,PP-5527-5529,Y-2014

17. Meikandaan T.P., Ramachandra Murthy A.,Study of damaged RC beams repaired by bonding of CFRP laminates,International Journal of Civil Engineering and Technology,V-8,I-2,PP-470-486,Y-2017

18. Meikandaan T.P., Ramachandra Murthy A.,Retrofittng of reinforced concrete beams using GFRP overlays,International Journal of Civil Engineering and Technology,V-8,I-2,PP-423-439,Y-2017

19. Meikandaan T.P., Ramachandra Murthy A.,Flexural behaviour of RC beam wrapped with GFRP sheets,International Journal of Civil Engineering and Technology,V-8,I-2,PP-452-469,Y-2017

20. Meikandaan T.P., Murthy A.R.,Experimental study on strengthening of rc beams using glass Fiber,International Journal of Civil Engineering and Technology,V-9,I-11,PP-959-965,Y-2018

21. Meikandaan T.P., Hemapriya M.,Use of glass FRP sheets as external flexural reinforcement in RCC Beam,International Journal of Civil Engineering and Technology,V-8,I-8,PP-1485-1501,Y-2017

22. Saraswathy R., Saritha B.,Planning of integrated satellite township at Thirumazhisai,International Journal of Applied Engineering Research,V-9,I-22,PP-5558-5560,Y-2014

23. Saritha B., Ilayaraja K., Eqyaabal Z.,Geo textiles and geo synthetics for soil reinforcement,International Journal of Applied Engineering Research,V-9,I-22,PP-5533-5536,Y-2014

24. Ambica A., Saritha B., Changring G., Singh N B., Rajen M., Salman Md.,Analysis of groundwater quality in and around Tambaram taluk, Kancheepuram district,International Journal of Civil Engineering and Technology,V-8,I-8,PP-1362-1369,Y-2017

25. Arunya A., Sarayu K., Ramachandra Murthy A., Iyer N.R.,Enhancement of durability properties of bioconcrete incorporated with nano silica,International Journal of Civil Engineering and Technology,V-8,I-8,PP-1388-1394,Y-2017

26. Ilayaraja K., Krishnamurthy R.R., Jayaprakash M., Velmurugan P.M., Muthuraj S.,Characterization of the 26 December 2004 tsunami deposits in Andaman Islands (Bay of Bengal, India),Environmental Earth Sciences,V-66,I-8,PP-2459-2476,Y-2012

27. Ilayaraja K.,Morphometric parameters of micro watershed in Paravanar sub-basin Cuddalore District,International

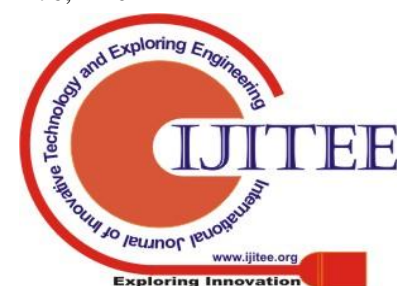


Journal of Civil Engineering and Technology,V-8,I-8,PP-1444-1449, Y-2017

28. Ilayaraja K., Singh R.K., Rana N., Chauhan R., Sutradhar N.,Site suitability assessment for residential areas in south Chennai region using remote sensing and GIS techniques,International Journal of Civil Engineering and Technology,V-8,I-8,PP-1468-1475,Y-2017

29. Ilayaraja K., Reza W., Kumar V., Paul S., Chowdhary R.,Estimation of land surface temperature of Chennai metropolitan area using Landsat images,International Journal of Civil Engineering and Technology,V-8,I-8,PP-1450-1456,Y-2017

30. Chitra R.,Experimental study on beam using steel fiber and latex,International Journal of Civil Engineering and Technology,V-8,I-8,PP-1395-1403,Y-2017

31. Chitra R.,Analysis of traffic and management at Kovilambakkam intersection,International Journal of Civil Engineering and Technology,V-8,I-8,PP-1433-1443,Y-2017

32. Aswathy M.,Experimental study on light weight foamed concrete,International Journal of Civil Engineering and Technology,V-8,I-8,PP-1404-1412,Y-2017

33. Aswathy M.,Wastewater treatment using constructed wetland with water lettuce (Eichornia Crasipies),International Journal of Civil Engineering and Technology,V-8,I-8,PP-1413-1421,Y-2017

34. Kiruthiga K., Anandh K.S., Gunasekaran K, Assessment of influencing factors on improving effectiveness and productivity of construction engineers, 2015, International Journal of Applied Engineering Research, V - 10,I -17,p -13849-13854.

\section{AUTHORS PROFILE}

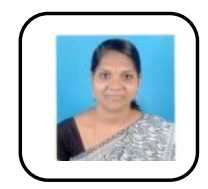

S. Thendral, Assistant Professor,,Department Of Civil Engineering,,Bharath Institution Of Higher Education And Research,TamilNadu, India

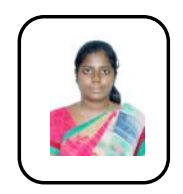

A.Arunya, Asistant Professor, Department Of Civil Engineering,,Bharath Institution of Higher Education And Research,TamilNadu, India

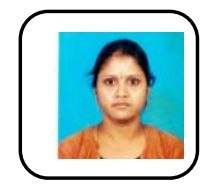

R. Chitra, Asistant Professor, Department Of Civil Engineering,,Bharath Institution of Higher Education And Research,TamilNadu, India 